\title{
Bali Beef Quality after the Application of Liquid Smoke in Feed Block during Fattening
}

\author{
Effendi Abustam ${ }^{1}$, Muhammad Irfan Said ${ }^{2}$, Muhammad Yusuf ${ }^{3}$ and N. Nahariah ${ }^{4}$
}

\begin{abstract}
The use of liquid smoke as an antioxidant and binder in beef was done in the form of community empowerment in the Cattle Breeders Group in District of Tanete Riaja. The activity aimed to improving the skills of cattle breeder groups in the application of technology in livestock, especially the use of liquid smoke in animal feed. The feed was the primary need for livestock which in certain seasons faced difficulties in providing it. The implementation method was in the application of feed products in the form of urea water coconut liquid-smoke multi-nutrient block (UCSMB). Three concentrations of liquid smoke were added to the feed, namely 0,10 and $20 \%$. The production of probiotic fermented rice straw was carried out as a source of fiber to complete feed entirely. The application of feed products was carried out on 12 male Bali beef aged 2-3 years for 45 days. After the cattle were slaughtered, the Longissimus dorsi dissection muscle was then aged for 0,7 and 14 days. The parameters of meat quality were $\mathrm{pH}$, water holding capacity (WHC), shear force of meat cooked value, and cooking loss. The results showed that meat quality increased with increasing concentration and aging time.
\end{abstract}

Keywords: Bali beef, fermented straw, liquid smoke, meat quality, UCSMB

\section{Introduction}

Cattle breeding which was dominated by Balinese cattle in Indonesia, especially in South Sulawesi, was characterized by traditional hereditary, extensive maintenance, with a relatively small number of cattle 1-5 heads per farmers. About 55\% of cattle that are raised are Balinese cattle (Bali Post, 2008). Nationally there were around 15.5 million cattle populations in Indonesia, most of which $(>80 \%)$ were in the hands of the people. The characteristics of cattle raising were straightforward, characterized by little maintenance amount, aiming for employment and as savings. Also, the input of livestock technology has not been used massively. The importance of cattle farms in Indonesia could be seen from the community's need for sources of animal protein derived from fresh meat and processed meat products such as meatballs. Fresh beef needs reached $2.56 \mathrm{~kg} /$ capita / day or 654,000 tons for 255,461,700 inhabitants of Indonesia in 2015 (Hartati, 2016). While the need for meatballs by Abustam et al. (2018) showed,the importance of beef meatballs for public consumption was characterized by around $60 \%$ of cattle slaughtered in slaughterhouses intended for meatballs (personal communication). In 2017 slaughtered cattle in Indonesia reached 1,114,748 (BPS. 2018), with an estimated weight of $50 \mathrm{~kg} / \mathrm{h}$ ead of meat to be produced with 33,442.4 tons/year of meatball production or 91.62 tons/day in Indonesia (Abustam et al., 2018).

Efforts to increase the isolation of cattle to meet the needs of fresh meat or beef meatballs could be made through more modern farms with the application of advanced 
technology through consideration of the maximum possible efficiency as possible. One approach that has been done so far to farmers was that livestock productivity increases were through community farmers' empowerment. This empowerment will achieve its goals if done correctly in groups of farmers or Micro Small and Medium Enterprises (MSMEs).

Efforts to improve the performance of Bali cattle was carried out through the application of technology that was easy to implement in raising livestock. Even though it was known that Bali cattle was able to adapt well to hostile environments with low feed quality as Sastradipradja (1990) stated, another advantage of Bali cattle was that percentage of the carcass could reach $52-57.7 \%$ with a lower fat content of about $4 \%$ (Payne and Hodges, 1997). In traditional raising in South Sulawesi, Bali beef fat levels were below 2\% (Abustam, 2012). The problem with the maintenance of Bali cattle was the provision of forage in the cage through cutting and transporting the forage required time and effort. Where in the dry season it became heavier because of the decreasing availability of forage.

Tanete Riaja Subdistrict as a region with a Bali cattle population that ranked the second highest (11,664 in 2012) in Barru District (BPS, 2013; Barru Animal Husbandry Service, 2013), has implemented livestock cages as the showroom. Farmers in groups conducted business to develop Bali cattle breeding and to fatten at home.

The main problem raised by livestock group partners, in general, could be concluded was the provision of feed. The consequence of livestock custody required farmers to provide forage in cutting and carrying, cutting elephant grass or paddy straw and giving it to cattle at home.

The application of probiotic paddy straw fermentation technology and supplement feeding in the form of Urea Coconut Water Liquid Smoke Multi-Nutrient Block (UCSMB) was carried out in the Application of Technology in 2015 with very satisfactory results (Abustam et al., 2015). In 2016 feed technology innovations were carried out through the manufacture and feeding of UCSMB block supplements which were added several levels of liquid smoke concentrations then given as feed fattening to cattle belonging to livestock groups. Through this technological innovation as a form of community empowerment, it was expected that it could be a solution to solving food availability which will have an impact on increasing the productivity of Bali beef in the showroom

\section{Materials and Methods}

The application of liquid smoke in feed block was carried out in the Sikapa farmers group during fattening of Bali beef.

This research utilized 12 head of Bali beef age 2-3 years old male. The animals received6 $\mathrm{kg}$ of probiotic fermented rice straw and 500 gr UCSMB per day during 45 of fattening. After the cattle were slaughtered, meat samples were taken on the outer portion (Longissimus dorsi muscle), then meat quality was observed at the Hasanuddin University Meat and Egg Processing Technology Laboratory.

This study used a complete randomized design of factorial pattern $3 \times 3$ where the first factor was the concentration of liquid smoke (0,10 and 20\%), and the second factor was 
the aging time (0.7 and 14 days).

The observed parameter was $\mathrm{pH}$, water holding capacity (WHC), shear force value of cooked meat (CMSF) and cooking loss (CL).

\subsection{Urea Coconut Water Liquid Smoke Multi-Nutrient Block (UCSMB)}

There are three different types of UCSMB which have different concentrations of liquid smoke in block feed formulations, namely concentrations of $0 \%, 10 \%$, and $20 \%$ with a rate of $2 \%$ in the formulation. The composition of feed supplements in the form of blocks can be seen in Table 1 .

Table 1. Feed Material Composition in UCSMB

\begin{tabular}{llccc}
\hline \multirow{2}{*}{ Feed Material } & \multicolumn{3}{c}{ Feed Material Composition $(\%)$ in Liquid Smoke Concentration } \\
\cline { 2 - 4 } & $0 \%$ & $10 \%$ & $20 \%$ \\
\hline 1. Coconut Water & 30 & 28 & 28 \\
2. Urea & 5 & 5 & 5 \\
3. & Rice Bran & 30 & 30 & 30 \\
4. & Cornmeal & 10 & 10 & 10 \\
5. Milled coconut meal & 10 & 10 & 10 \\
6. Cement & 10 & 2 & 10 \\
7. & Mineral cattle & 2 & 3 & 2 \\
8. Salt & 3 & 2 & 3 \\
9. & Liquid Smoke & 0 & & 2 \\
\hline
\end{tabular}

Source: Abustam et al., (2015;2018)

\subsection{Probiotic fermented rice straw}

Fermented straw products were produced from fermented rice straw using probiotics Organic Liquid Supplement (SOC) for 10-12 days. $150 \mathrm{~kg}$ of rice straw was stacked several piles after sprinkled with diluted SOC probiotic solution with a ratio of $30 \mathrm{ml}$ SOC dissolved into 45 liters of clean water. Among the piles were sprinkled with very fine rice bran. After 10-12 days the rice straw has been fermented and ready to be used as cattle feed. Fermented straw protein content was $2 \%$ higher than straw before fermentation to $7.87 \%$.

\section{$2.3 \mathrm{pH}$ Measurement}

$\mathrm{pH}$ measurement was done using a Lutron $\mathrm{pH}$ meter pocket $\mathrm{PH}-201$ with electrode type (spear tip) PE-06 HD specifically for meat.

\subsection{Water holding capacity (WHC) measurement}

WHC measurement was conducted about Hamm Method 1972; $0.3 \mathrm{~g}$ of meat on a filter paper placed between two stainless steel plates was given a weight of $35 \mathrm{~kg}$ for five minutes. As can be seen from the filter paper, the area was covered by the flattened meat sampling, and it was wet around the area. Both areas were measured. The size of the wet area was obtained by subtracting the area covered with meat from the total area. WHC was calculated based on the percentage of the wet area of the total area (Abustam, 2012). 


\subsection{Measurement of shear force value of cooked meat}

Shear force value of cooked meat measurement is meant to see the tenderness of meat by using CD Shear Force. Where samples of meat in the form of a cylinder with a length of $1 \mathrm{~cm}$ and 0.5 inches in diameter were placed in the hole of the CD shear force that the blade with a thick $1 \mathrm{~mm}$ to cut samples. The higher the load to cut off the sample of the meat is tough. Shear force values expressed in $\mathrm{kg} / \mathrm{cm}^{2}$ (Abustam, 2012).

\subsection{Measurement of cooking loss}

Cooking loss (\%) was calculated by a comparison between the weight that is lost during cooking with the weight of the sample before cooking (Soeparno, 2005).

\subsection{Data analysis}

Data were analyzed by analysis of variance (ANOVA) and followed by the LSD test. Meanwhile, the real influence was based on Steel and Torrie (Steel and Torrie, 1991) by using the SPSS program (SPSS 16.0, SPSS Ltd., West Street, Woking, Surrey, UK).

\section{Results and Discussion}

\subsection{Meat Quality}

The quality of fattened meat from Bali beef through the provision of fermented probiotic and UCSMB feed could be explained through the measurement of several meat quality parameters, including $\mathrm{pH}$, water holding capacity (WHC), cooked meat shear force value, and cooking loss. The significance level of the mean value of meat quality can be seen in Table 2 and Figure 1, 2, 3, 4, and 5.

Table 2: Significance level of mean value of $\mathrm{pH}, \mathrm{WHC}, \mathrm{CMSF}$, and CL

\begin{tabular}{ccccc}
\hline Treatments & pH Value & WHC $(\%)$ & $\begin{array}{c}\text { CMSF } \\
\left(\mathrm{kg} / \mathrm{cm}^{2}\right)\end{array}$ & CL (\%) \\
\hline UCSMB & Sig: 0.01 & Sig: NS & Sig: 0.01 & $\begin{array}{c}\text { Sig: } 0.01 \\
-0 \%\end{array}$ \\
$6.52^{\mathrm{a}} \pm 0.21$ & $18.38+1.99$ & $8.24^{\mathrm{a}} \pm 2.00$ & $23.41^{\mathrm{a}} \pm 7.30$ \\
$-10 \%$ & $6.02^{\mathrm{b}} \pm 0.39$ & $18.58 \pm 2.90$ & $4.13^{\mathrm{b}} \pm 0.36$ & $15.38^{\mathrm{b}} \pm 2.52$ \\
$-20 \%$ & $5.98^{\mathrm{bc}} \pm 0.45$ & $20.23 \pm 3.66$ & $3.68^{\mathrm{b}} \pm 0.26$ & $13.42^{\mathrm{b}} \pm 1.62$ \\
Aging time & Sig: 0.01 & Sig: 0.01 & Sig: 0.01 & Sig: 0.01 \\
- 0 day & $5.87^{\mathrm{a}} \pm 0.61$ & $15.79^{\mathrm{a}} \pm 0.48$ & $6.12^{\mathrm{a}} \pm 3.29$ & $20.41^{\mathrm{a}} \pm 6.94$ \\
-7 days & $6.40^{\mathrm{b}} \pm 0.26$ & $20.47^{\mathrm{b}} \pm 1.61$ & $4.60^{\mathrm{b}} \pm 1.25$ & $18.54^{\mathrm{a}} \pm 7.36$ \\
-14 days & $6.25^{\mathrm{c}} \pm 0.06$ & $20.93^{\mathrm{b}} \pm 1.32$ & $5.34^{\mathrm{c}} \pm 3.01$ & $13.25^{\mathrm{b}} \pm 1.64$ \\
\hline
\end{tabular}

Description: numbers with different letter notation on the same column stated a significant difference $(\mathrm{P}<0.01$ highly significant); NS: Non significant

WHC: Water Holding Capacity; CMSF: Cooked Meat Shear Force Value; CL: Cooking Loss

\section{$3.2 \mathrm{pH}$ value of beef}

Changes in the $\mathrm{pH}$ value of Bali beef can be seen in Table 2, Figure 1 and 2 


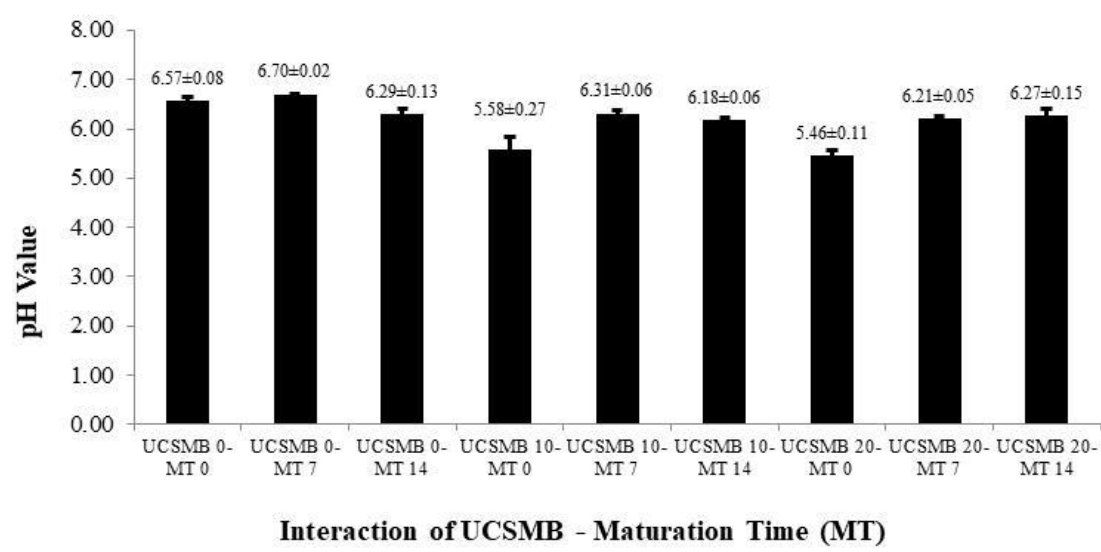

Figure 1. The value of $p H$ of meat samples on different urea coconut water smoke molasses block (UCSMB) concentrations and aging time (MT) on meat; (1) UCSMB $B_{0}-M T_{0}=$ without using UCSMB and aging time; (2) $U C S M B_{0}-M T_{7}=$ without using UCSMB and aging time for 7 days; (3) $U C S M B_{0}-M T_{14}=$ without using $U C S M B$ and aging time for 14 days; (4) UCSMB ${ }_{10}-M T_{0}=U C S M B 10 \%$ and without aging time; (5) $U C S M B_{10}-M T_{7}=U C S M B 10 \%$ and aging time for 7 days; (6) UCSMB ${ }_{10}-M T_{14}=U C S M B 10 \%$ and aging time for 14 days; (7) UCSMB $20-M T_{0}=U C S M B 20 \%$ and without aging time; (8) UCSMB ${ }_{20}-M T_{7}=$ UCSMB 20\% and aging time for 7 days; (9) $U C S M B_{20}-M T_{14}=U C S M B 20 \%$ and aging time for 14 days

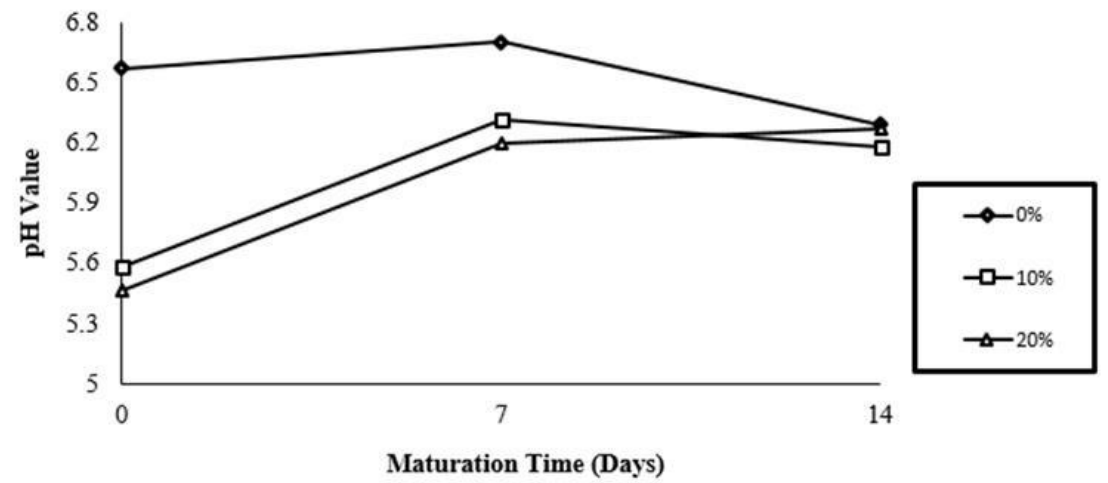

Figure 2. Interaction of concentration liquid smoke and aging time of $\mathrm{pH}$ value

Analysis of variance showed that the concentration of liquid smoke in block feed had a significant effect $(\mathrm{P}<0.01)$ on the $\mathrm{pH}$ value of meat. The higher the concentration of liquid smoke in UCSMB, the lower the final $\mathrm{pH}$ reaches $8.28 \%$ lower at a concentration of $20 \%$.

However, there is no real difference between the concentration of $10 \%$ and $20 \%$. This indicates that liquid smoke given in block feed for 45 days can reduce the final $\mathrm{pH}$ of Bali beef.

Analysis of variance showed that the aging time had a very significant effect $(\mathrm{P}<0.01)$ on the $\mathrm{pH}$ value of meat. The higher the aging time, the higher the final $\mathrm{pH}$ reaches $6.30 \%$ ( 0.37 points) at 14 days aging. 
There is an interaction between the concentration of liquid smoke with the aging time marked by a decrease in $\mathrm{pH}$ with increasing concentration of liquid smoke and an increase in $\mathrm{pH}$ with increasing aging time. The interaction of concentration liquid smoke and aging time on $\mathrm{pH}$ value can be seen in Figure 2.

\subsection{Water Holding Capacity}

Changes in WHC values based on liquid smoke concentrations and aging times were shown in Table 2 and Figure 3.

Different concentrations of liquid smoke in UCSMB produced approximately the same WHC, even though there was a tendency for WHC to increase with increasing concentration of liquid smoke. At the concentration of liquid smoke $20 \%$ WHC reached $20.23 \%$ slightly higher than at a concentration of $10 \%$ and without liquid smoke.

The more aging time increased, the higher the WHC reached 32.55\% higher than the initial time of aging ( 0 days), even though there was no significant difference between the aging period of 7 and 14 days. Increasing WHC with increasing aging time indicated that liquid smoke in UCSMB given to Bali beef for 45 days was able to improve meat quality through increasing WHC during aging. Previous studies showed a decrease in WHC of muscle Longissimus dorsi Bali beef with increasing storage time where at 8 hours WHC reached $31.40 \%$ (Abustam and $\mathrm{M}$. Ali, 2012). The other research showed that aging time increased WHC (Abustam et al., 2018).

There was no interaction between the concentration of liquid smoke with the time of aging indicating that the increase in WHC in the concentration of liquid smoke was different even though it was not really in line with the increase in WHC during aging.

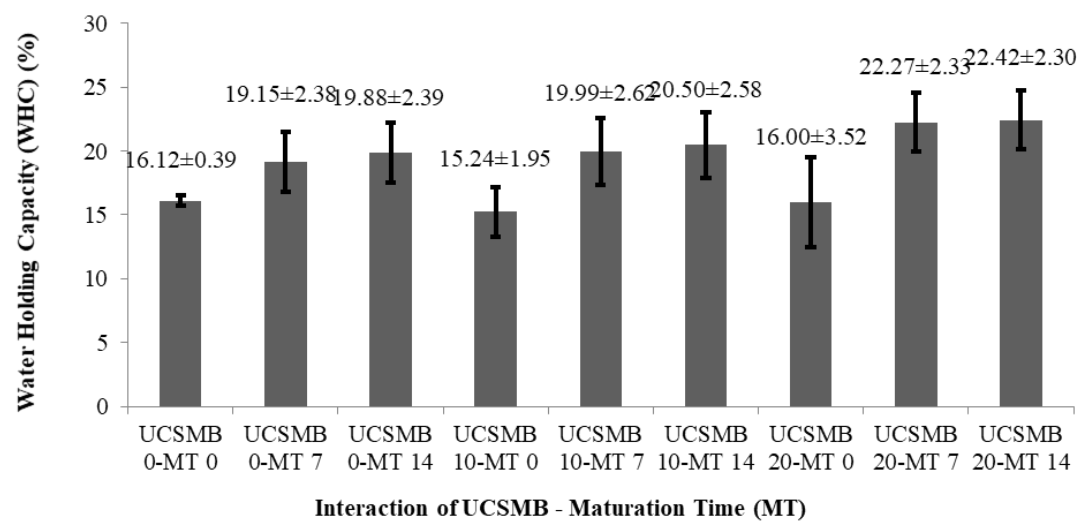

Figure 3. The value of WHC (\%) of meat samples on different urea coconut water smoke molasses block (UCSMB) concentrations and aging time (MT) on meat; (1) UCSMBO-MTO = without using UCSMB and aging time; (2) UCSMBO-MT7 = without using UCSMB and aging time for 7 days; (3) UCSMBO-MT14 = without using UCSMB and aging time for 14 days; (4) UCSMB10-MTO = UCSMB 10\% and without aging time; (5) UCSMB10-MT7 = UCSMB 10\% and aging time for 7 days; (6) UCSMB10-MT14 = UCSMB $10 \%$ and aging time for 14 days; (7) UCSMB20-MTO = UCSMB 20\% and without aging time; (8) UCSMB20-MT7 = UCSMB 20\% and aging time for 7 days; (9) UCSMB20-MT14 = UCSMB 20\% and aging time for 14 days 


\subsection{Shear Force of Cooked Meat $\left(80^{\circ} \mathrm{C}-15^{\prime}\right)$}

Changes in the value of cooking meat shear force $\left(80^{\circ} \mathrm{C}-15\right.$ ) based on the concentration of liquid smoke and the aging time are shown in Table 2 and Figure 4.

The breaking power of cooked meat decreased to $55.34 \%$ with increasing concentrations of liquid smoke in feed. This indicates the ability of liquid smoke to increase the muscle tenderness of Longissimus dorsi which has been cooked at $80^{\circ} \mathrm{C}$ for 15 minutes. The use of liquid smoke directly in fresh meat showed the concentration of liquid smoke did not significantly affect the shear force value of cooked meat $\left(80^{\circ} \mathrm{C}-15^{\prime}\right)$, even though there was a tendency to decrease the breaking power of cooked meat with increasing concentration of liquid smoke (Abustam et al., 2014). In this case liquid smoke, up to $2 \%$ in the feed can inhibit protein oxidation characterized by increased tenderness during aging. Bhattacharya et al. (2006) stated that if the protein undergoes oxidation, it can decrease the tenderness of the meat. Rowe et al. (2004) suggested that protein oxidation will change the WHC and tenderness of the meat.

Analysis of variance showed that the aging time affects the shear force value meat cooked, where the longer the aging time the shear force value of meat cooked decreased and at 14 days' aging the breaking power of cooked meat value up to $27.82 \%$ lower than the 0 -day aging time. Decreased raw meat breakdown during aging due to the work of proteolytic enzymes that digest proteins during aging resulting in a decrease in the shear force value of raw meat. However, the decrease in shear force value of meat cooked was higher than the shear force value of raw meat of $18.94 \%$ in the 14 th day of aging. Heating meat at a temperature of $80^{\circ} \mathrm{C}$ caused dissolution of collagen which resulted in the deposition of raw meat can explain this as stated Abustam (2012).

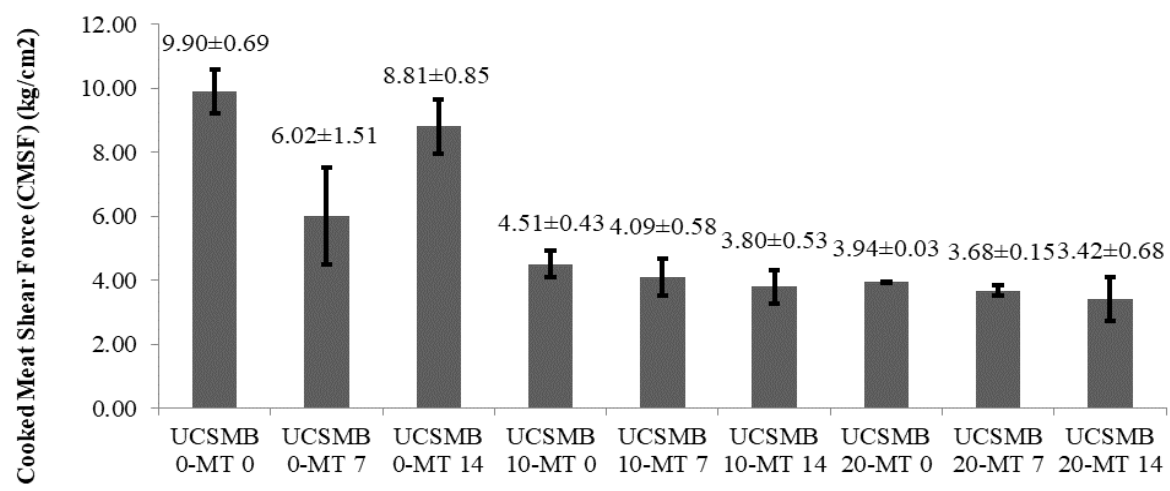

Interaction of UCSMB - Maturation Time (MT)

Figure 4. The value of MSF $(\mathrm{kg} / \mathrm{cm} 2)$ of meat samples on different urea coconut water smoke molasses block (UCSMB) concentrations and aging time (MT) on meat; (1) UCSMBO-MTO = without using UCSMB and aging time; (2) UCSMBO-MT7 = without using UCSMB and aging time for 7 days; (3) UCSMBO-MT14 = without using UCSMB and aging time for 14 days; (4) UCSMB10-MTO = UCSMB 10\% and without aging time; (5) UCSMB10-MT7 = UCSMB 10\% and aging time for 7 days; (6) UCSMB10-MT14 = UCSMB $10 \%$ and aging time for 14 days; (7) UCSMB20-MTO = UCSMB 20\% and without aging time; (8) UCSMB20-MT7 = UCSMB 20\% and aging time for 7 days; (9) UCSMB20-MT14 = UCSMB 20\% and aging time for 14 days Description: Numbers with Different Letters Notation in the Same Columns and Rows State Highly Significant Differences $(P<0.01)$. 


\subsection{Cooking losses}

Changes in the value of cooking loss $\left(80^{\circ} \mathrm{C}-15^{\prime}\right)$ based on the concentration of liquid smoke and the aging time were shown in Table 2 and Figure 5.

The cooking losses decreased with the increasing concentration of liquid smoke in UCMSB and reached a decrease of $34.30 \%$ at a concentration of $20 \%$, even though there was no significant difference between concentrations of $10 \%$ and $20 \%$. A decrease in cooking losses at higher concentrations of liquid smoke in UCSMB feed gave a positive result that the concentration level decreased cooking losses which would have implications for the increase in yield of meat and processed meat products. This was in line with WHC which tended to increase with increasing concentration of liquid smoke in UCSMB feed even though there was no significant difference between concentration levels (see Table 2).

Increasing aging time decreased cooking losses and reached a decrease of $35.08 \%$ in the 14th day of aging, even though there was no significant difference between the 0th and seventh-day aging. This indicates that liquid smoke in UCSMB's feed was able to inhibit the loss of free and semi-free water and the possibility of water bound in protein (WHC) during aging which will have implications for high yields in processed meat products even though the meat has undergone aging. This is in line with WHC which was increasing with increasing aging time (see Table 2).

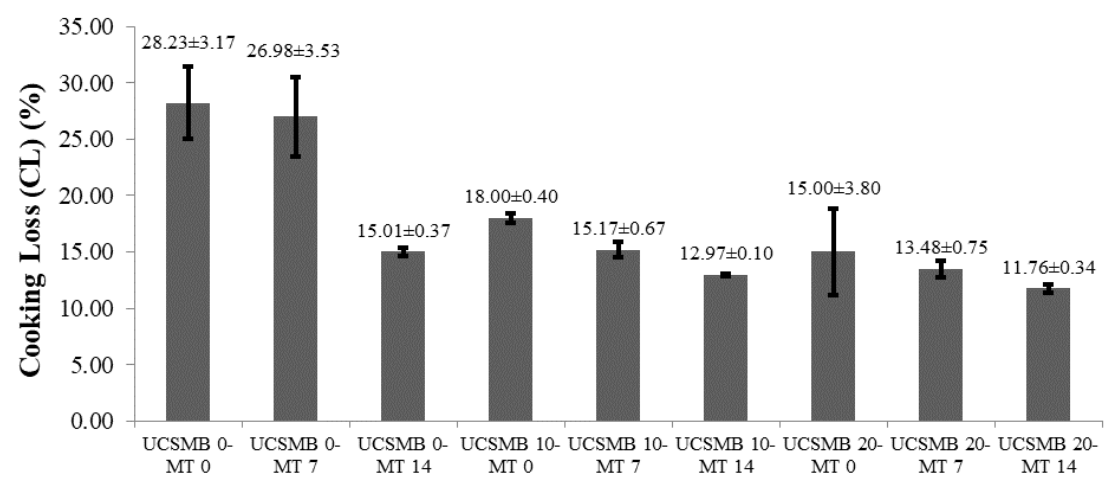

Interaction of UCSMB - Maturation Time (MT)

Figure 5. The value of CL (\%) of meat samples on different urea coconut water smoke molasses block (UCSMB) concentrations and aging time (MT) on meat; (1) UCSMBO-MTO = without using UCSMB and aging time; (2) UCSMBO-MT7 = without using UCSMB and aging time for 7 days; (3) UCSMBO-MT14 = without using UCSMB and aging time for 14 days; (4) UCSMB10-MTO = UCSMB 10\% and without aging time; (5) UCSMB10-MT7 = UCSMB 10\% and aging time for 7 days; (6) UCSMB10-MT14 = UCSMB 10\% and aging time for 14 days; (7) UCSMB20-MTO = UCSMB 20\% and without aging time; (8) UCSMB20-MT7 $=$ UCSMB 20\% and aging time for 7 days; (9) UCSMB20-MT14 = UCSMB 20\% and aging time for 14 days.

\section{Conclusion}

This current study reveals that quality of Bali beef increases with increasing concentration of liquid smoke in UCSMB feed and aging time. The concentration of 
liquid smoke increases $\mathrm{pH}$ value, shear force value and cooking loss. While aging time increases $\mathrm{pH}$ value, WHC and decreases shear force value and cooking loss.

\section{Acknowledgments}

The authors express their gratitude to the Directorate of Research and Community Service of Ministry of Science, Technology and Higher Education for the implementation of this Community Service Project through the 2016 PPM Grant No. 005/SP2H/PPM/DRPM/II/2016.

\section{Reference}

Abustam, E. 2012. Meat Science: Aspects of production, Chemistry, and Quality. $1^{\text {st }}$ Ed. Masagena Press, Makassar (Indonesian)

Abustam, E and H. M. Ali. 2012. Improvement of functional properties of beef Bali (Longissimus dorsal) through the addition of liquid smoke post mortem and rigor time. Proc. National Seminar "Increased Production and Quality Bali National Beef" Bali, 14 September 2012. Center for The Study of Bali Cattle Udayana University. pp. 64-73(Indonesian)

Abustam, E., M. I. Said, M. Yusuf, and H.M. Ali. 2014. Characteristics of quality Bali beef (M. Longissimus dorsi) after addition of smoke flour drying by the oven, freeze dry, and dry spray on the level and different storage time. Proc. National conference of animal husbandry. Hasanuddin University. PP: 174-180 (Indonesian)

Abustam, E, M. Yusuf, M.I. Said, and M. Zain Mide. 2015. IbM Showroom Bali cattle in district Tanete Riaja of Barru Regency. Reports of PPM DP2M Dikti, Faculty of Animal Science Hasanuddin University (Indonesian).

Abustam, E, M.I. Said, M. Yusuf. 2018.Antioxidant Activity of Liquid Smoke in Feed Supplement Block on Meat Functional of Muscle Longissimus dorsi. IOP Conf. Series: Earth and Environmental Science 119 (2018) 012046 DOI: 10.1088/1755-1315/119/1/012046.

Abustam, E, M.I. Said, M. Yusuf. 2018. Organoleptic Characteristics of Bali Beef Meatballs Based on Collagen Concentration in UKKMB and Time of Maturation to Support Sustainable Livestock Husbandry. Proc. Abstract First International Conference on Multidisciplinary Approaches for Sustainable Rural Development. LP2M Unsoed Purwokerto. November 14-15, 2018 (Indonesian).

Bali Post. 2008. Sapi Bali, Plasma Nutfah yang harusDilestarikan http://www.balipost.com/BaliPostcetak/2008/1/18/b9.htm. (Akses, 1/1/2011).

Bhattacharya, D., Kandeepan, G., and Vishnuraj. M.R. 2016. Protein Oxidation in Meat and Meat ProductsA Review. Journal of Meat Science and Technology. April-June, 2016.Vol 4 Issue 2 Pages 44-52.

BPS, 2013. Kabupaten Barru Dalam Angka 2013. Badan Pusat Statistik Kabupaten Barru

BPS. 2018. Statistik Indonesia 2018. Peternakan. https://www.bps.go.id. Diakses 3/10/2018

Dinas Peternakan Barru, 2013. Laporan Dinas Peternakan Kabupaten Barru

Hartati, E.S. 2016. Phenomenon of Price Increase in Beef. Economic Analysis. Kompas, Monday 23 May 2016 Page. 15.

Payne, W.J.A. and J. Hodges. 1997. Tropical Cattle: Origin, Breeds, and Breeding Policies. Blackwell Science

Rowe L, Maddock J, Lonergan KRSM, Huff-Lonergan E 2004 Influence of early postmortem protein oxidation on beef quality. J. Anim. Sci., 82 (3), 785-793.

Sastradipradja, D. 1990. The internal potential of Bali cattle as one of the germplasm sources to support the development of beef cattle and livestock development nationally. Proc. Bali Cow National Seminar. Denpasar, September 20-22. Denpasar: Faculty of Animal Husbandry, Udayana University. Pages A-47 - A54.

Soeparno. 2005. Meat Science and Technology. Gadjah Mada University Press, Yogyakarta.

Steel, R.G.D., and Torrie, J.H. 1991. Principles and Procedures of Statistics. McGraw Hill, Book Co. Inc., New York. 